\title{
Determination of design criteria for UASB reactors as a wastewater pretreatment system in tropical small communities
}

\author{
$I^{*}$ A. A. Azimi and ${ }^{2}$ M. Zamanzadeh \\ ${ }^{I}$ Department of Environmental Engineering, Graduate School of the Environment, University of Tehran, Iran \\ ${ }^{2}$ Department of Environmental Health Engineering, School of Public Health, Tehran University of Medical Sciences, Iran
}

\begin{abstract}
A pilot scale study was set up to investigate the principle design parameters of up flow anaerobic sludge blanket (UASB) reactors for treating wastewater of small communities in the tropical regions of Iran. A steel pipe with a diameter of $600 \mathrm{~mm}$ and a height of $3.6 \mathrm{~m}$ was used as the reactor in which a digestion and a 3-phase separator element had a volume of 0.848 and $0.17 \mathrm{~m}^{3}$ respectively. During this study, which lasted for 203 days, two distinct phases were carried out according to the ambient temperature. The temperature of the wastewater entering the reactor was naturally ranged from 22 to $26{ }^{\circ} \mathrm{C}$ and no heat exchanger was used. The hydraulic retention times including $2,4,6,8$, and 10 hours with various loading rates of 0.95 to $5.70 \mathrm{~kg} \mathrm{COD} / \mathrm{m}^{3} / \mathrm{day}$ for colder period and from 1.35 to $6.40 \mathrm{~kg} \mathrm{COD} / \mathrm{m}^{3} /$ day for warmer period were examined. On the basis of the results the optimal hydraulic retention time for warmer period with a $2.20 \mathrm{~kg} \mathrm{COD} / \mathrm{m}^{3} /$ day organic loading rate was 6 hours which BOD5, COD and TSS removal efficiency were 71, 63 and 65percent respectively . During the colder period the removal ratio of BOD5, COD and TSS with an optimal hydraulic retention time of 8 hours and organic loading rate of $1.22 \mathrm{~kg} \mathrm{COD} / \mathrm{m}^{3} /$ day were 54,46 and 53 percent respectively.
\end{abstract}

Key words: UASB reactor, HRT, small communities, wastewater pretreatment, tropical regions

*Corresponding Author, E-mail: aaazimi@chamran.ut.ac.ir

\section{Introduction}

In recent years there has been a growing interest in anaerobic treatment of wastewaters. Compared to aerobic growth, anaerobic fermentation produces much less biomass from the same amount of COD removal (Tchobanoglous, et al., 1991). Upflow anaerobic sludge blanket (UASB) reactor is a popular anaerobic reactor for both high and low temperature (Dinsdale, et al., 1997). The UASB reactor is by far the most widely used high rate anaerobic system for anaerobic sewage treatment. In the case of a relatively low strength wastewater such as sewage, the hydraulic retention time rather than organic loading rate is the most important parameter determining the shape and the size of the UASB reactor. The several favorable characteristics of anaerobic processes, such as low cost, operational simplicity, low biosolids production and considerable biogas production, together with suitable environmental conditions have contributed to highlight anaerobic systems for the treatment of sewage in small communities of tropical regions. Although different types of anaerobic treatment systems have been applied to a great variety of industrial wastes, so far the anaerobic treatment concept is rarely used for sewage. Experimental results of anaerobic sewage treatment are restricted to the use of the anaerobic filter, fluidized and expanded bed and the UASB with and without a threephase separator. To compare the different anaerobic treatment systems, the UASB concept looks the most attractive option for sewage treatment (Van Haandel and Lettinga, 1994). The present work evaluates an important design parameter for a UASB reactor, that is, Hydraulic Retention Time (HRT). The performance of a UASB reactor was assessed by applying various hydraulic retention times. This research was carried out to study the feasibility of UASB process as a pretreatment alternative for Ahwaz sewage treatment. This city is located in tropical region of Iran, where in general the ambient and wastewater temperature is appropriate for anaerobic process application. 


\section{Materials and Methods}

The UASB reactor used in this study was made with a pipe of $600 \mathrm{~mm}$ inner diameter, a total height of $3.6 \mathrm{~m}$ and a total volume of $1 \mathrm{~m}^{3}$ (10001), of which approximately 17 and 83 percent were set up as gas/solid/liquid separation and digestion, respectively. This reactor was fed with raw wastewater taken downstream from the screening unit of the Ahwaz Wastewater Treatment Plant. Because of the fluctuations in pumping station of the plant, maintenance of constant flow rates with pumps was almost impossible; therefore, an intermediate tank was used to pump the wastewater to the reactor. In order to develop the desired hydraulic retention times, the influent flow rate to the reactor was changed. Following each change in the HRT the reactor was allowed to reach steady state. The wastewater was introduced at the bottom of the reactor though a tube with a $50 \mathrm{~mm}$ diameter and distributed over the cross-section by means of a perforated plexiglass plate, which was placed about $40 \mathrm{~cm}$ above the feed tube. A tap was placed at the bottom of the reactor to remove the accumulated solids. Sample ports were placed at $0.5 \mathrm{~m}$ intervals throughout the height of digestion zone with an additional port at the bottom of the reactor (the port used for solids removal). In order to investigate the various HRTs effect on the efficiency of UASB, this study was divided into two phases including cold (November to February, 2001) and warm (July to September, 2002) periods. The performance of the reactor was monitored through 24-hour flow weighted composite samples, taken from inlet and sample ports. In other words, the amount of each individual sample that is added to the total mixture was proportional to the wastewater flow at the time the sample was taken. The daily samples were frozen and at the end of each week the samples were melted and mixed and the analysis were performed. The analyses included 5-day Biochemical Oxygen Demand $\left(\mathrm{BOD}_{5}\right)$, Chemical Oxygen Demand (COD), Total Suspended Solids (TSS) and alkalinity. It should be mentioned that the average wastewater temperature and $\mathrm{pH}$ were monitored daily. All the analyses were carried out according to the Standard Methods (APHA et al., 1995). Table 1 provides the flow rate and upflow velocity of the influent wastewater into the reactor in the various hydraulic retention times.

\section{Results}

Figure 1 shows the wastewater temperature throughout the study. The results indicated that wastewater temperature in warm and cold periods ranged from $22-26{ }^{\circ} \mathrm{C}$ and $20-22{ }^{\circ} \mathrm{C}$, respectively. As indicated in Table 2, the UASB reactor was exposed to various HRTs including $10,8,6,4$, and $2 \mathrm{~h}$. In the experiments carried out with the UASB reactor, the optimum $\mathrm{HRT}$ in terms of $\mathrm{BOD}_{5}$ and COD removal was $6 \mathrm{~h}$ in which the organic load applied to the reactor was $2.20 \mathrm{~kg}$ $\mathrm{COD} / \mathrm{m}^{3} . \mathrm{d}$ and $1.14 \mathrm{BOD}_{5} / \mathrm{m}^{3}$.d, producing a removal efficiency of $71 \%\left(\mathrm{BOD}_{5}\right)$ and $63 \%$ (COD). The optimum TSS removal efficiency (61\%) occurred in an HRT of $4 \mathrm{~h}$ in which the suspended solids loading was $2.26 \mathrm{~kg}$ $\mathrm{TSS} / \mathrm{m}^{3}$.d (Figure 2). The same HRTs were experienced for cold period (Table 2). At this time, the optimum $\mathrm{BOD}_{5}$ and $\mathrm{COD}$ removal efficiency occurred in an HRT of $8 \mathrm{~h}$ in which the organic loading was $1.22 \mathrm{~kg} \mathrm{COD} / \mathrm{m}^{3} . \mathrm{d}$ and $0.65 \mathrm{~kg} \mathrm{BOD}{ }_{5} / \mathrm{m}^{3}$. d. As indicated in Fig. 3 , the UASB reactor performance in comparison with warm period was significantly lower, with removal efficiency reaching $54 \%\left(\mathrm{BOD}_{5}\right)$ and $46 \%$ (COD). Although the optimum HRT for TSS removal was similar to the warm period, that is, $4 \mathrm{~h}$, the reactor performance in TSS removal $(45 \%$ for suspended solids with a loading of $1.67 \mathrm{~kg} \mathrm{TSS} / \mathrm{m}^{3}$.d) was again lower in comparison to warm period.

\section{Discussion \\ Influence of temperature}

As indicated in Figure 2 and 3, in a same HRT the increase in wastewater average temperature from 21 to $24{ }^{0} \mathrm{C}$ increased the $\mathrm{BOD}_{5}$ and COD removal efficiency. This result is in agreement with the earlier work of De Man, 1990 and Kennedy et al., 1981.This is also true for TSS removal efficiency because in a same HRT an increase in wastewater temperature from 21 to $24{ }^{0} \mathrm{C}$ increased the removal performance of the UASB reactor. The increase in the removal efficiency can probably be attributed to a high rate of hydrolysis of organic matter by microorganisms; or to the decrease of viscosity and consequently increase of settling velocity. 
Table 1: The characteristics of the influent wastewater

\begin{tabular}{|c|c|c|c|c|c|c|c|c|c|c|c|}
\hline $\begin{array}{l}\overrightarrow{0} \\
\stackrel{0}{0} \\
\stackrel{2}{0}\end{array}$ & Week & HRT & BOD & COD & TSS & $\begin{array}{l}\text { D. } \\
\stackrel{0}{0} . \\
\stackrel{2}{0}\end{array}$ & Week & HRT & BOD & COD & TSS \\
\hline & 1 & \multirow[t]{4}{*}{2} & 211 & 431 & 276 & & 18 & \multirow[t]{4}{*}{2} & 252 & 485 & 299 \\
\hline & 2 & & 210 & 417 & 265 & & 19 & & 251 & 485 & 312 \\
\hline & 3 & & 220 & 399 & 263 & & 20 & & 253 & 487 & 328 \\
\hline & 4 & & 227 & 401 & 261 & & Mean \pm SD & & $252 \pm 1$ & $485.7 \pm 1.15$ & $313 \pm 14.53$ \\
\hline & Mean \pm SD* & \multirow{7}{*}{4} & $213.7 \pm 8.04$ & $415.7 \pm 15.01$ & $268 \pm 6.70$ & & Range & & $251-253$ & $485-487$ & $299-328$ \\
\hline & Range & & $210-227$ & $399-431$ & $261-276$ & & 21 & \multirow[t]{2}{*}{4} & 251 & 484 & 338 \\
\hline & 5 & & 215 & 408 & 253 & & 22 & & 256 & 493 & 343 \\
\hline & 6 & & 207 & 394 & 244 & & Mean \pm SD & & $253.5 \pm 3.54$ & $488.5 \pm 6.36$ & $340.5 \pm 3.54$ \\
\hline & 7 & & 204 & 386 & 230 & & Range & & $251-256$ & $484-493$ & $338-343$ \\
\hline & Mean \pm SD & & $208.7 \pm 5.69$ & $396 \pm 11.14$ & $242.3 \pm 11.59$ & & 23 & \multirow[t]{2}{*}{6} & 256 & 493 & 343 \\
\hline & Range & & $204-215$ & $386-408$ & $230-253$ & & 24 & & 260 & 501 & 350 \\
\hline & 8 & \multirow[t]{4}{*}{6} & 191 & 362 & 223 & \multirow{4}{*}{ 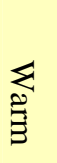 } & Mean \pm SD & & $258 \pm 2.83$ & $497 \pm 5.66$ & $346.5 \pm 4.95$ \\
\hline \multirow{3}{*}{$\frac{\rho}{2}}$. & 9 & & 191 & 363 & 238 & & Range & \multirow{3}{*}{8} & $256-260$ & $493-501$ & $343-350$ \\
\hline & 10 & & 197 & 373 & 230 & & 25 & & 260 & 502 & 351 \\
\hline & 11 & & 198 & 375 & 212 & & 26 & & 260 & 501 & 353 \\
\hline & Mean \pm SD & \multirow{5}{*}{8} & $194.3 \pm 3.77$ & $368.3 \pm 6.70$ & $225.8 \pm 11.03$ & & Mean \pm SD & & $260 \pm 0$ & $501.5 \pm 0.71$ & $352 \pm 1.41$ \\
\hline & Range & & 191-198 & $362-375$ & $212-238$ & & Range & & 260 & $501-502$ & $351-353$ \\
\hline & 12 & & 195 & 370 & 211 & & 27 & \multirow[t]{2}{*}{10} & 265 & 510 & 356 \\
\hline & 13 & & 197 & 375 & 227 & & 28 & & 263 & 506 & 353 \\
\hline & 14 & & 199 & 378 & 241 & & Mean \pm SD & & $264 \pm 1.41$ & $508 \pm 2.83$ & $354.5 \pm 2.12$ \\
\hline & Mean \pm SD & \multirow{5}{*}{10} & $197 \pm 2$ & $374.3 \pm 4.04$ & $226.3 \pm 15.01$ & & Range & & $263-265$ & $506-510$ & $353-356$ \\
\hline & Range & & 195-199 & $370-378$ & 211-241 & & & & & & \\
\hline & 15 & & 199 & 379 & 235 & & & & & & \\
\hline & 16 & & 197 & 373 & 234 & & & & & & \\
\hline & 17 & & 192 & 365 & 225 & & & & & & \\
\hline & Mean \pm SD & & $196 \pm 3.61$ & $372.3 \pm 7.02$ & $231.3 \pm 5.51$ & & & & & & \\
\hline & Range & & $192-199$ & $365-379$ & $225-235$ & & & & & & \\
\hline
\end{tabular}

*Mean \pm Standard Deviation 


\section{Influence of HRT}

It is observed (Figure 2) that the UASB reactor for $\mathrm{BOD}_{5}$ and COD removal efficiency increases with increasing HRT from 2 to $10 \mathrm{~h}$. However, the results indicate that there is little benefit in operating the reactor at an HRT exceeding $8 \mathrm{~h}$ in cold period $\left(\mathrm{T}=20-22{ }^{\circ} \mathrm{C}\right)$ and $6 \mathrm{~h}$ in warm period $\left(\mathrm{T}=22-26{ }^{\circ} \mathrm{C}\right)$ because little additional removal of $\mathrm{BOD}_{5}$ and $\mathrm{COD}$ was achieved. Therefore, the optimum HRT for $\mathrm{BOD}_{5}$ and COD removal can be considered 6 and $8 \mathrm{~h}$ for warm and cold period, respectively. Other studies (Haskoning and Euroconsult, 1990; Vieira and Garcia, 1991; Van Haandel and Lettinga, 1994; Yu et al., 2000) are in good agreement with the result presented here. Low $\mathrm{BOD}_{5}$ and COD removal efficiency in HRTs less than $6 \mathrm{~h}$ is probably owing to the less stabilized character of the sludge resulting in a stronger tendency for flotation (Van Haandel and Lettinga, 1994). Also, further increase in HRT above $6 \mathrm{~h}$ did not lead to a significant increase in $\mathrm{BOD}_{5}$ and COD removal efficiency. This is probably attributed to the fact that a long HRT above $6 \mathrm{~h}$ might lead to a low concentration of fermentative substrates ( $\mathrm{Yu}$ et al., 2000). In addition, the study conducted by $\mathrm{Yu}$ et al. (2000), showed that in thermophilic conditions of UASB reactor the sludge bed, blanket solution and effluent had a maximum ATP concentration (biological activity) around an HRT of $5 \mathrm{~h}$. As a consequence, further increase or decrease of HRT from $5 \mathrm{~h}$ will result in decrease of ATP concentration; thus, it might be expected that in thermophilic conditions $\left(\mathrm{T}=45-55{ }^{\circ} \mathrm{C}\right.$ ) the optimum HRT is about $5 \mathrm{~h}$. Based on the results (Figure 2 and 3), an increase in HRT from 2 to $10 \mathrm{~h}$ increased TSS removal efficiency; however, the optimum HRT for TSS removal is about $4 \mathrm{~h}$. The low efficiency of TSS removal in short HRTs is due to excessive turbulence in the UASB reactor; therefore, the likelihood of entrapping suspended and colloidal solids is reduced. On the other hand, little additional removal of suspended solids at an HRT longer than $6 \mathrm{~h}$ is attributed to the low suspended solids concentrations remained at higher HRTs.

\footnotetext{
Simultaneous influence of temperature, HRT and organic Loading

Removal performance of the UASB reactor in terms of $\mathrm{BOD}_{5}, \mathrm{COD}$ and TSS depends on temperature, HRT and organic loading rate (Table 2). On the basis of the obtained results,
}

the maximum removal of $\mathrm{BOD}_{5}(75 \%), \mathrm{COD}$ $(65 \%)$ and TSS $(73 \%)$ with an organic loading of $1.35 \mathrm{~kg} \mathrm{COD} / \mathrm{m}^{3} . \mathrm{d}, 0.70 \mathrm{~kg} \mathrm{BOD}{ }_{5} / \mathrm{m}^{3} . \mathrm{d}$ and $2.50 \mathrm{~kg}$ TSS $/ \mathrm{m}^{2}$.d occurred at an HRT of $10 \mathrm{~h}$ in warm period. Increasing the HRT from 6 to $10 \mathrm{~h}$ resulted only in 4,2 and 8 percent additional removal of $\mathrm{BOD}_{5}, \mathrm{COD}$ and TSS respectively; therefore, construction of the UASB reactor with an HRT exceeding $6 \mathrm{~h}$ will not be economical for an incoming wastewater with a temperature range of 22 to $26{ }^{\circ} \mathrm{C}$. Since wastewater treatment plant design is based on critical conditions (cold period) it is more rational to choose $8 \mathrm{~h}$ as a design HRT and $1.22 \mathrm{~kg} \mathrm{COD} / \mathrm{m}^{3}$.d or $0.65 \mathrm{~kg} \mathrm{BOD}{ }_{5} / \mathrm{m}^{3}$.d as a design organic loading for the UASB reactor. Consequently, the removal efficiency in terms of $\mathrm{BOD}_{5}$ and $\mathrm{COD}$ in warm period will be 19 and 17 percent higher than cold period. It should be noted that although the optimum HRT for TSS removal is $4 \mathrm{~h}(61 \%$ for warm and $45 \%$ for cold periods), selection of an HRT of $8 \mathrm{~h}$ as a design HRT would increase TSS removal up to 71 and 53 percent in warm and cold periods, respectively.

\section{Conclusion}

The results obtained in this research demonstrated that the UASB reactor could be used as an effective pretreatment alternative for municipal wastewater in tropical regions. From the data presented here the following conclusions can be drawn:

- During the warm period, which the wastewater temperature varied from 22 to 26 ${ }^{0} \mathrm{C}$, the optimum HRT in the UASB reactor with an organic loading of $2.20 \mathrm{~kg} \mathrm{COD} / \mathrm{m}^{3} . \mathrm{d}$ and $1.14 \mathrm{~kg} \mathrm{BOD} 5 / \mathrm{m}^{3}$.d was $6 \mathrm{~h}$. The removal efficiency for BOD5 and COD was 71 and 63 percent, respectively.

- During the cold period, which the wastewater temperature was in the range of 20 to $22{ }^{0} \mathrm{C}$, the optimum HRT in the UASB reactor with an organic loading of $1.22 \mathrm{~kg}$ $\mathrm{COD} / \mathrm{m}^{3} . \mathrm{d}$ and $0.65 \mathrm{~kg} \mathrm{BOD} 5 / \mathrm{m}^{3}$.d was $6 \mathrm{~h}$. The removal efficiency for BOD5 and COD was 54 and 46 percent, respectively.

- Applying a suspended solids loading of $4.21 \mathrm{~kg}$ TSS $/ \mathrm{m}^{2}$.d (cold period) and $5.96 \mathrm{~kg}$ $\mathrm{TSS} / \mathrm{m}^{2}$.d (warm period), the UASB performance with an optimum HRT of $4 \mathrm{~h}$ for TSS removal was 61 and 45 percent for warm and cold periods, respectively. 

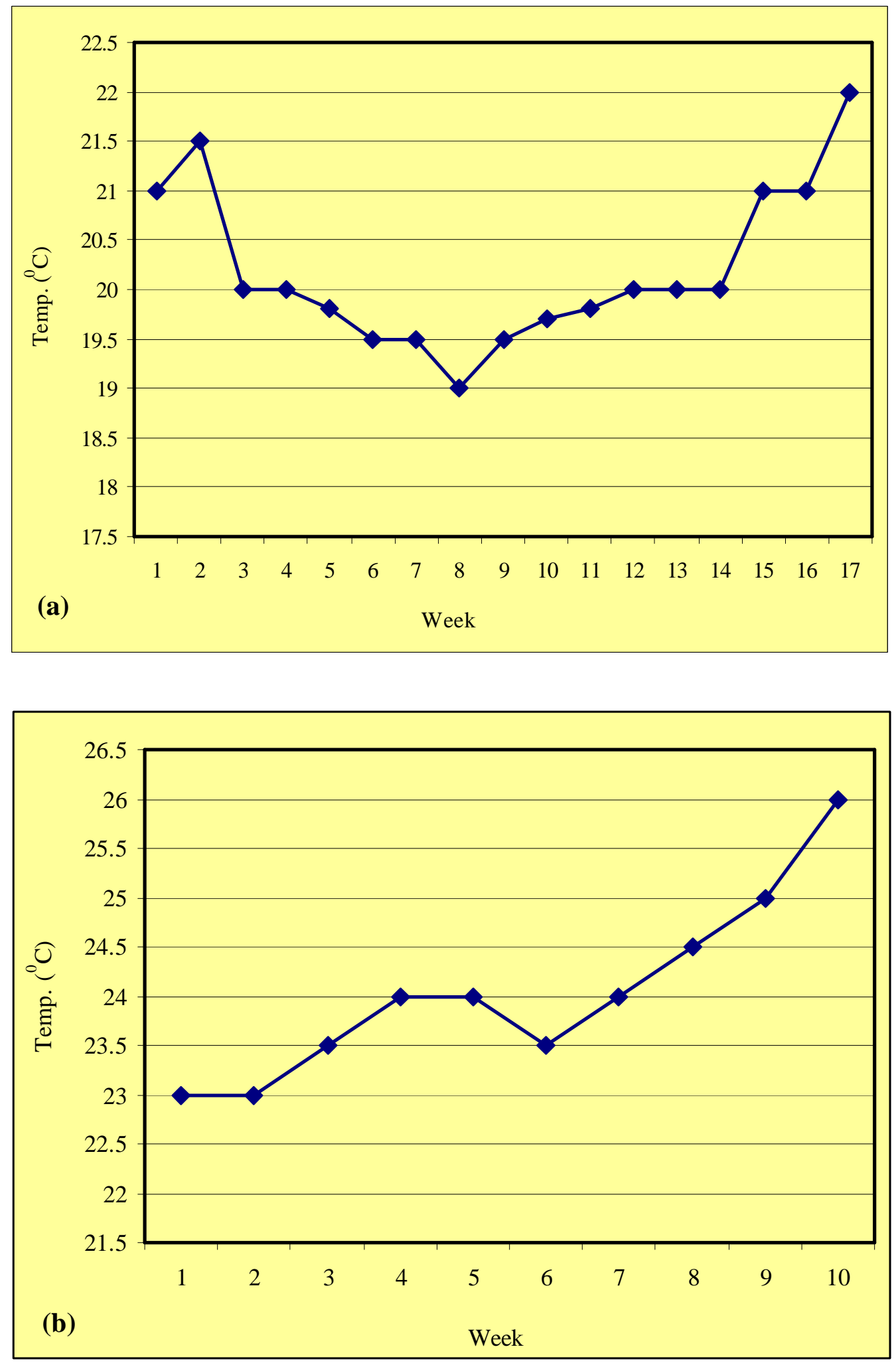

Figure 1: Variations of wastewater temperature in (a) cold and (b) warm periods 


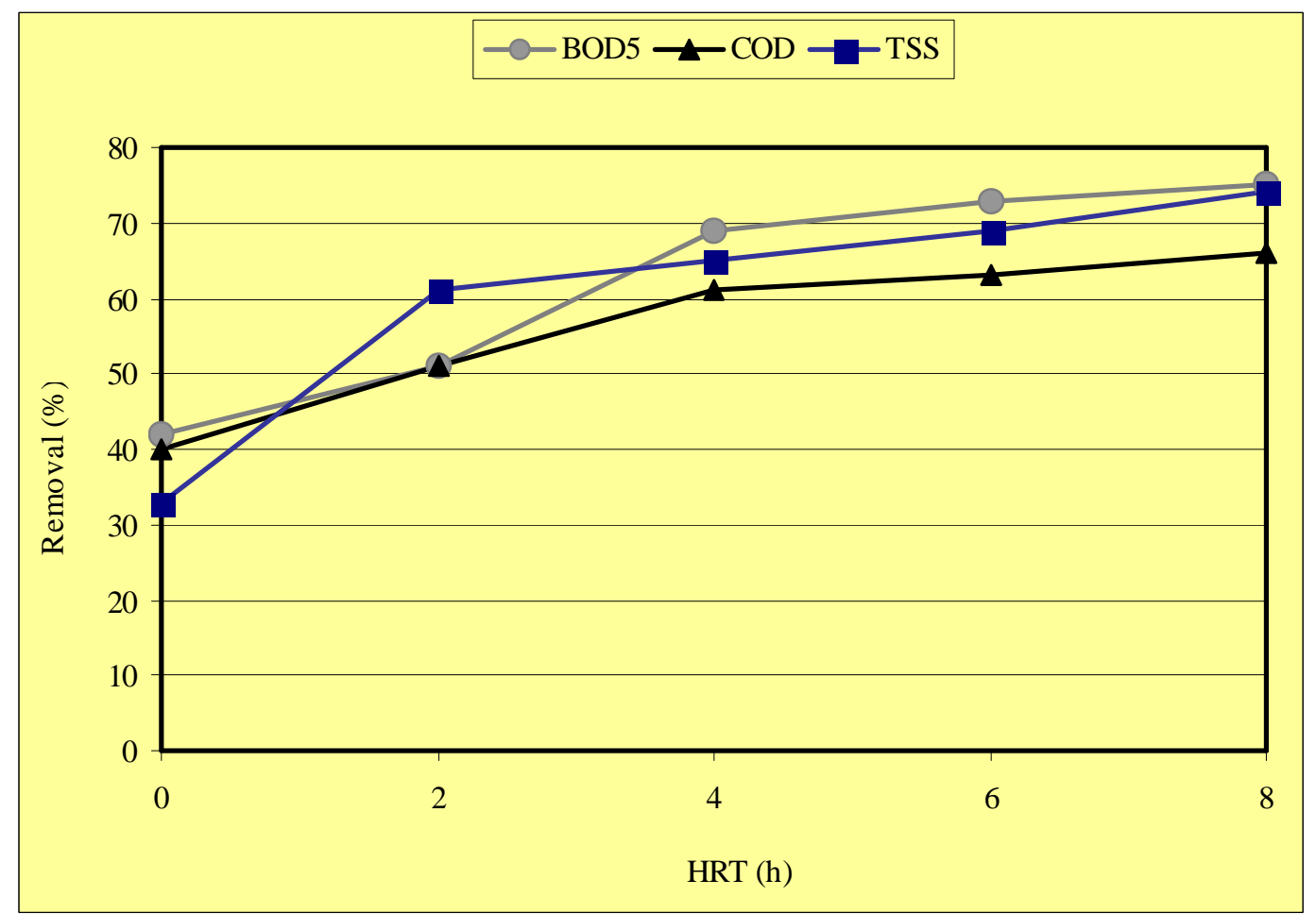

Figure 2: Average $\mathrm{COD}, \mathrm{BOD}_{5}$ and TSS removal percentage with hydraulic retention time in warm period

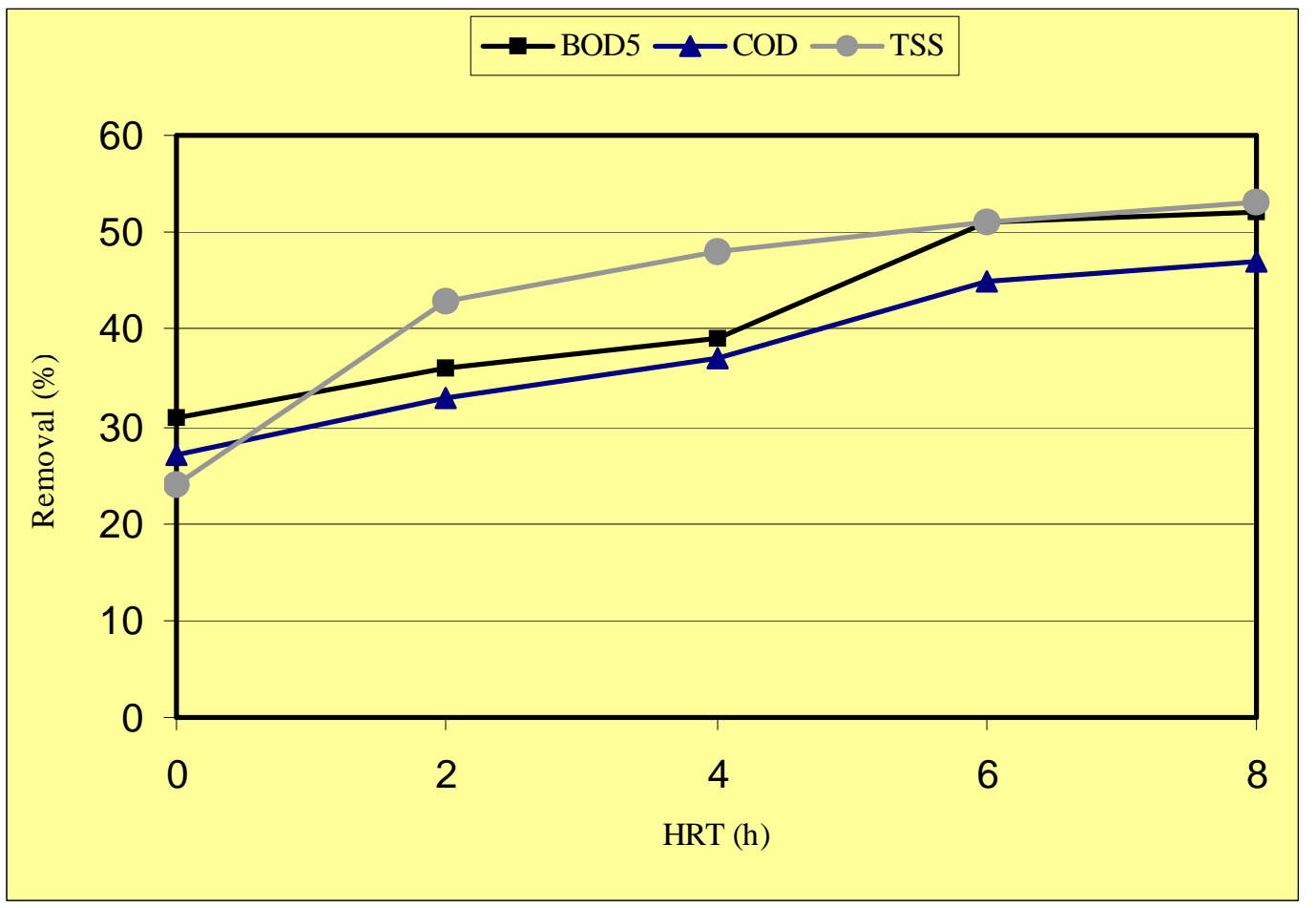

Figure 3: Average COD, $\mathrm{BOD}_{5}$ and TSS removal percentage with hydraulic retention time in cold period 
Table 2: Operational conditions in the UASB reactor

\begin{tabular}{|c|c|c|c|c|c|c|c|}
\hline \multirow[t]{2}{*}{ Period } & \multirow[t]{2}{*}{ Week } & \multirow{2}{*}{$\begin{array}{l}\text { HRT } \\
\text { (h) }\end{array}$} & \multicolumn{2}{|c|}{$\begin{array}{c}\text { Organic Loading } \\
\left(\mathrm{kg} / \mathrm{m}^{3} . \mathrm{d}\right)\end{array}$} & \multicolumn{3}{|c|}{$\begin{array}{c}\text { Removal Ratio } \\
(\%)\end{array}$} \\
\hline & & & BOD & COD & BOD & COD & TSS \\
\hline \multirow{17}{*}{ Cold } & 1 & \multirow{4}{*}{2} & 3.00 & 5.70 & 35 & 29 & 25 \\
\hline & 2 & & 2.90 & 5.51 & 32 & 27 & 23 \\
\hline & 3 & & 2.77 & 5.27 & 28 & 25 & 22 \\
\hline & 4 & & 2.78 & 5.30 & 27 & 22 & 22 \\
\hline & 5 & \multirow{3}{*}{4} & 1.15 & 2.70 & 39 & 35 & 45 \\
\hline & 6 & & 1.36 & 2.60 & 34 & 32 & 43 \\
\hline & 7 & & 1.34 & 2.54 & 31 & 28 & 41 \\
\hline & 8 & \multirow{4}{*}{6} & 0.84 & 1.60 & 43 & 38 & 48 \\
\hline & 9 & & 0.84 & 1.60 & 39 & 37 & 48 \\
\hline & 10 & & 0.86 & 1.64 & 35 & 35 & 47 \\
\hline & 11 & & 0.87 & 1.65 & 36 & 34 & 44 \\
\hline & 12 & \multirow{3}{*}{8} & 0.64 & 1.22 & 54 & 46 & 53 \\
\hline & 13 & & 0.65 & 1.23 & 50 & 44 & 51 \\
\hline & 14 & & 0.65 & 1.24 & 49 & 44 & 47 \\
\hline & 15 & \multirow{3}{*}{10} & 0.52 & 1.00 & 56 & 49 & 55 \\
\hline & 16 & & 0.52 & 0.98 & 49 & 47 & 54 \\
\hline & 17 & & 0.50 & 0.96 & 48 & 44 & 51 \\
\hline \multirow{11}{*}{ Warm } & 18 & \multirow{3}{*}{2} & 3.33 & 6.41 & 39 & 35 & 29 \\
\hline & 19 & & 3.31 & 6.41 & 41 & 38 & 34 \\
\hline & 20 & & 3.34 & 6.43 & 48 & 45 & 36 \\
\hline & 21 & \multirow{2}{*}{4} & 1.65 & 3.20 & 50 & 49 & 59 \\
\hline & 22 & & 1.70 & 3.25 & 54 & 52 & 61 \\
\hline & 23 & \multirow{2}{*}{6} & 1.12 & 2.17 & 66 & 57 & 64 \\
\hline & 24 & & 1.15 & 2.20 & 71 & 63 & 65 \\
\hline & 25 & \multirow{2}{*}{8} & 0.85 & 1.65 & 73 & 64 & 68 \\
\hline & 26 & & 0.85 & 1.65 & 73 & 64 & 71 \\
\hline & 27 & \multirow{2}{*}{10} & 0.71 & 1.35 & 74 & 65 & 71 \\
\hline & 28 & & 0.70 & 1.34 & 75 & 65 & 73 \\
\hline
\end{tabular}

- For designing a UASB reactor in tropical regions (wastewater temperature ranged from 20 to $26{ }^{\circ} \mathrm{C}$ ) it is recommended to choose: HRæ8 $\mathrm{h}$; Organic Loading $=1.22 \mathrm{~kg}$ $\mathrm{COD} / \mathrm{m}^{3} . \mathrm{d}$ or $0.65 \mathrm{~kg} \mathrm{BOD} 5 / \mathrm{m}^{3} . \mathrm{d}$.

\section{References}

APHA, AWWA and WPCF, Standard methods for the examination of water and wastewater. $19^{\text {th }}$ Ed.. Washington DC, 1995

Dinsdale, R. M., Hawkes, F. R., Hawkes, D. L., comparison of mesophilic and themophilic upflow anaerobic sludge blanket reactors treating instant coffee production wastewater. Wat. Res., 31: 163-169, 1997

De Man, A. W. A, Anaerobic purification of raw sewage with the aid of granular sludge in UASB reactors. Report Agricultural University of Wageningen, Department of Water Pollution Control, 1990

Haskoning and Euroconsult, Monitoring report of the 5 MLD UASB treatment plant at KanpurTechnical Report, 1990
Kennedy, K. J. and Van den Berg, L., Effect of temperature and overloading on the performance of anaerobic fixed film reactors. Presented at the $36^{\text {th }}$ Industrial Waste Conference, Purdue University, Lafayatte, USA, 1981

Tchobanoglous, G., Burton, F. L., Wastewater engineering: Treatment, disposal and reuse. $3^{\text {rd }}$ Ed..394, 426. New York, McGraw Hill, 1991

Van Haandel. A. C. and Lettinga, G., Anaerobic sewage treatment: a practical guide for regions with a hot climate. John Wiley and Sons, 222, 1994

Vieira, S. M. M. and Garcia, A. D. Jr, Sewage treatment by $U A S B$ reactor. Operation results and recommendations for design and utilization. Presented at the $6^{\text {th }}$ International IAWPRC Symposium, Sao Paulo, Brazil, 1990

Yu, J., Chen, H., Ji, M., and Yue, P. L., Distribution and change of microbial activity in combined $U A S B$ and AFB reactors for wastewater treatment. Bioprocess Engineering, 22: 315-322, 2000 
